\title{
Biodiversitas Echinodermata pada Ekosistem Lamun di Perairan Pulau Karimunjawa, Jepara
}

\author{
Reni Ria Yunita*, Suryanti Suryanti, dan Nurul Latifah \\ Departemen Sumberdaya Akuatik, Fakultas Perikanan dan IImu Kelautan, Universitas Diponegoro \\ J.. Prof. Soedarto, SH. Tembalang, Semarang 50275 \\ Email : reniriayunita@gmail.com
}

\section{Abstract \\ Biodiversity of Echinoderms in the Seagrass Ecosystem in Karimunjawa Island, Jepara}

The seagrass ecosystem is an important ecosystem as the place of feeding ground, nursery ground, and spawning ground. One of the biotas living in the seagrass was Echinoderms. This research aims to determine the density of seagrass and biodiversity of Echinoderms and the relationship between the seagrass density with the abundance of Echinoderms in the waters of Karimunjawa Island. The sampling methods used in this research is purposive sampling with two stations at a different location and each station there were three transect lines. The types of seagrass found in the waters of Karimunjawa Island are eight species i.e.: Thalassia hemprichii, Cymodocea rotundata, Enhalus acoroides, Syringodium isoetifolium, Cymodocea serrulata, Halophila minor, Halophila ovalis and Halodule uninervis. The type of Echinoderms found consists of three different classes i.e., Asteroidea, Echinoidea, and Holothuroidea. Class of Asteroidea, there is 1 type i.e., Archaster typicus. Class of Echinoidea, there are 3 types i.e., Diadema setosum, Laganum central, and Laganum depressum. Class of Holothuroidea, there is 1 type i.e., Holothuria atra. The value of the diversity index ( $\mathrm{H}$ ') of Echinoderms ranged from 1.24 to 1.49. The range of index values of diversity ( $H$ ') of Echinoderms in Karimunjawa Island has medium species diversity. The results of this research show that the value of seagrass correlation with Echinodermata $(r)$ is 0.458, it means that the relationship between them is close enough and the higher density of seagrass then the abundance of echinoderms is lower.

Keywords: Biodiversity; echinoderms; seagrass; Karimunjawa Island

\begin{abstract}
Abstrak
Ekosistem lamun merupakan ekosistem penting sebagai tempat feeding ground, nursery ground, dan spawning ground. Salah satu biota yang hidup di ekosistem lamun adalah Echinodermata. Penelitian ini bertujuan untuk mengetahui kerapatan lamun dan biodiversitas Echinodermata serta hubungan antara kerapatan lamun dengan kelimpahan Echinodermata di perairan Pulau Karimunjawa. Teknik sampling yang digunakan dalam penelitian ini adalah purposive sampling dengan dua stasiun pada lokasi yang berbeda dan masing-masing stasiun terdapat 3 line transek. Line transek ditarik secara tegak lurus pantai sepanjang 50 meter dari pertama kali ditemukan lamun. Pengamatan yang dilakukan meliputi jenis dan jumlah lamun, jenis dan jumlah Echinodermata yang ditemukan pada setiap transek serta pengukuran parameter lingkungan perairan. Jenis lamun yang ditemukan di perairan Pulau Karimunjawa terdapat 8 jenis yaitu Thalassia hemprichii, Cymodocea rotundata, Enhalus acoroides, Syringodium isoetifolium, Cymodocea serrulata, Halophila minor, Halophila ovalis dan Halodule uninervis. Jenis Echinodermata yang ditemukan terdiri dari 3 kelas yang berbeda yaitu Asteroidea, Echinoidea, dan Holothuroidea. Kelas Asteroidea terdapat 1 jenis yaitu Archaster typicus, kelas Echinoidea terdiri dari 3 jenis yaitu Diadema setosum, Laganum central, dan Laganum depressum, sedangkan kelas Holothuroidea dijumpai 1 jenis yaitu Holothuria atra. Nilai indeks keanekaragaman (H') Echinodermata berkisar 1,24 - 1,49. Kisaran nilai indeks keanekaragaman ( $\left.\mathrm{H}^{\prime}\right)$ Echinodermata di Pulau Karimunjawa memiliki keanekaragaman jenis sedang. Hasil penelitian menunjukkan nilai
\end{abstract}


korelasi lamun dengan Echinodermata $(r)-0,458$ yang berarti hubungan diantara keduanya cukup erat dan semakin rapat lamun maka kelimpahan Echinodermata semakin rendah.

Kata Kunci : Biodiversitas; Echinodermata; lamun; Pulau Karimunjawa

\section{PENDAHULUAN}

Ekosistem padang lamun merupakan hamparan lamun yang terletak diantara ekosistem mangrove dan terumbu karang. Lamun merupakan satu-satunya tumbuhan berbunga (Angiospermae) yang mampu hidup pada salinitas tinggi dan terendam air (Azkab, 2006). Biota yang berasosiasi dengan ekosistem lamun beragam, mulai dari ikan, Mollusca, Arthropoda, Penyu, Dugong dan Echinodermata. Echinodermata merupakan biota asosiasi yang mempunyai peranan penting dalam ekosistem padang lamun. Ekosistem padang lamun dan Echinodermata memiliki hubungan timbal balik yang saling menguntungkan. Keuntungan tersebut adalah padang lamun merupakan tempat tinggal dan mencari makan bagi Echinodermata dan sebaliknya Echinodermata sebagai pendaur ulang nutrient yaitu dengan memakan detritus yang pada akhirnya akan bermanfaat bagi ekosistem padang lamun (Hadi, 2011) dan sebagai pembersih lingkungan. Oleh karena itu kelangsungan ekosistem padang lamun akan berpengaruh terhadap biota yang bergantung hidup di dalamnya.

Echinodermata adalah bagian dari biodiersitas kelautan, (Supono et al., 2014). Biodiversitas Echinodermata pada ekosistem padang lamun perlu diketahui untuk pengelolaan ekosistem lamun, mengingat telah terjadi kerusakan ekosistem lamun. Menurut Kawaroe et al., (2016) bahwa sekitar 30-40 \% kondisi ekosistem karena tekanan dari manusia dalam berbagai aktivitas seperti pariwisata, olahraga serta budidaya. Kajian biodiversitas oleh Iken et al., (2010) dikatakan penting untuk memahami pola ekologis dan fungsi ekosistem, sebagai pengelolaan pemanfaatan sumberdaya kelautan serta identifikasi prioritas konservasi. Lebih lanjut menurut Hadi (2011) Echinodermata mempunyai cara dan kemampuan dalam menentukan lokasi yang cocok untuk tempat hidupnya, sehingga perbandingan jenis dan kelimpahan Echinodermatadi suatu lokasi pada waktu yang berbeda perlu untuk dipelajari.

Penelitian tentang biodiversitas Echinodermata banyak dilakukan di berbagai tempat (Yusron, 2010; Yusron, 2013; Yusron, 2016) dan penelitian hubungan biodiversitas Echinodermata dengan lamun pernah dilakukan di Kepulauan Seribu (Oktavianty et al., 2014), sedangkan penelitian biodiversitas Echinodermata di Kepulauan Karimunjawa belum diteliti. Kepulauan Karimunjawa terdiri dari beberapa pulau diantaranya yaitu pulau Karimunjawa, Pulau Kemujan, Pulau Parang, Pulau Nyamuk dan Pulau-pulau kecil lainya. Oleh karena itu pada penelitian ini penulis membatasi wilayah penelitian hanya terfokus di Pulau Karimunjawa dengan kajian mengenai biodiversitas Echinodermata pada ekosistem padang lamun.

Penelitian ini bertujuan untuk mengetahui kerapatan lamun dan biodiversitas Echinodermata di perairan Pulau Karimunjawa serta untuk mengetahui hungan antara kerapatan lamun dan kelimpahan Echinodermata di Pulau Karimunjawa yang dilaksanakan pada bulan Maret 2018.

\section{MATERI DAN METODE}

Materi penelitian ini adalah jenis-jenis Echinodermata dan lamun yang ditemukan di perairan Pulau Karimunjawa. Adapun metode pengumpulan dilakukan dengan metode purposive sampling. Lokasi penelitian adalah Pulau Karimunjawa, yang termasuk dalam Kawasan Taman Nasional Karimunjawa, Taman Nasional Karimunjawa secara geografis terletak pada koordinat $5^{\circ} 40^{\prime} 39^{\prime \prime}-5^{\circ} 55^{\prime} 00^{\prime \prime}$ LS dan $110^{\circ} 05^{\prime} 57^{\prime \prime}-110^{\circ} 31^{\prime}$ 15" BT (BTNKJ, 2016).

Pengamatan objek penelitian
menggunakan metode line transek
sepanjang 50 meter. Satu stasiun terdiri dari 3 
line transek dengan jarak antara line transek adalah 25 meter. Line transek ditarik sepanjang 50 meter kearah laut dari pertama kalinya ditemukan lamun dan pengamatan dilakukan setiap $10 \mathrm{~m}$ sekali. Pengamatan lamun dan Echinodermata dilakukan dengan kuadran transek ukuran $1 \times 1 \mathrm{~m}$ (Hartati et al., 2012). Pengamatan lamun dilapangan meliputi jenis lamun, jumlah individu dan tegakan. Kerapatan lamun dihitung dengan jumlah tegakan atau pucuk spesies lamun yang ditemukan di dalam kotak. Lamun yang ditemukan di setiap kotak diidentifikasi langsung di lokasi penelitian dari bentuk daun, rimpang, bunga dan buah-buahan. Kerapatan spesies lamun adalah total jumlah spesies lamun individu dalam satu unit satuan diukur (McKenzie and Yoshida, 2009). Sedangkan pengamatan Echinodermata meliputi jenis, dan jumlah individu. Echinodermata yang dihitung dan diamati adalah Echinodermata yang berada dalam transek pengalamatan, kemudian Echinodermata di foto untuk identifikasi dan dokumentasi. Identifikasi spesies yang ditemukan di Pulau Karimunjawa dilakukan dengan menggunakan metode cek list. Metode cek list adalah metode yang digunakan untuk identifikasi spesies dengan mencocokkan gambar yang sudah ada beserta keterangannya (Ali et al., 2016). Selain data lamun dan Echinodermata juga dilakukan pengambilan data parameter fisika kimia perairan, antara lain, suhu, salinitas, $\mathrm{pH}$,, kecerahan, substrat, dan total bahan organik sedimen.

Data lapangan kemudian diolah untuk mendapatkan data kerapatan lamun, kelimpahan Echinodermata dan stuktur komunitas Echinodermata yang meliputi indeks keanekaragaman, keseragaman, dan dominasi serta mengetahui pola sebaran (Ali et al., 2016)

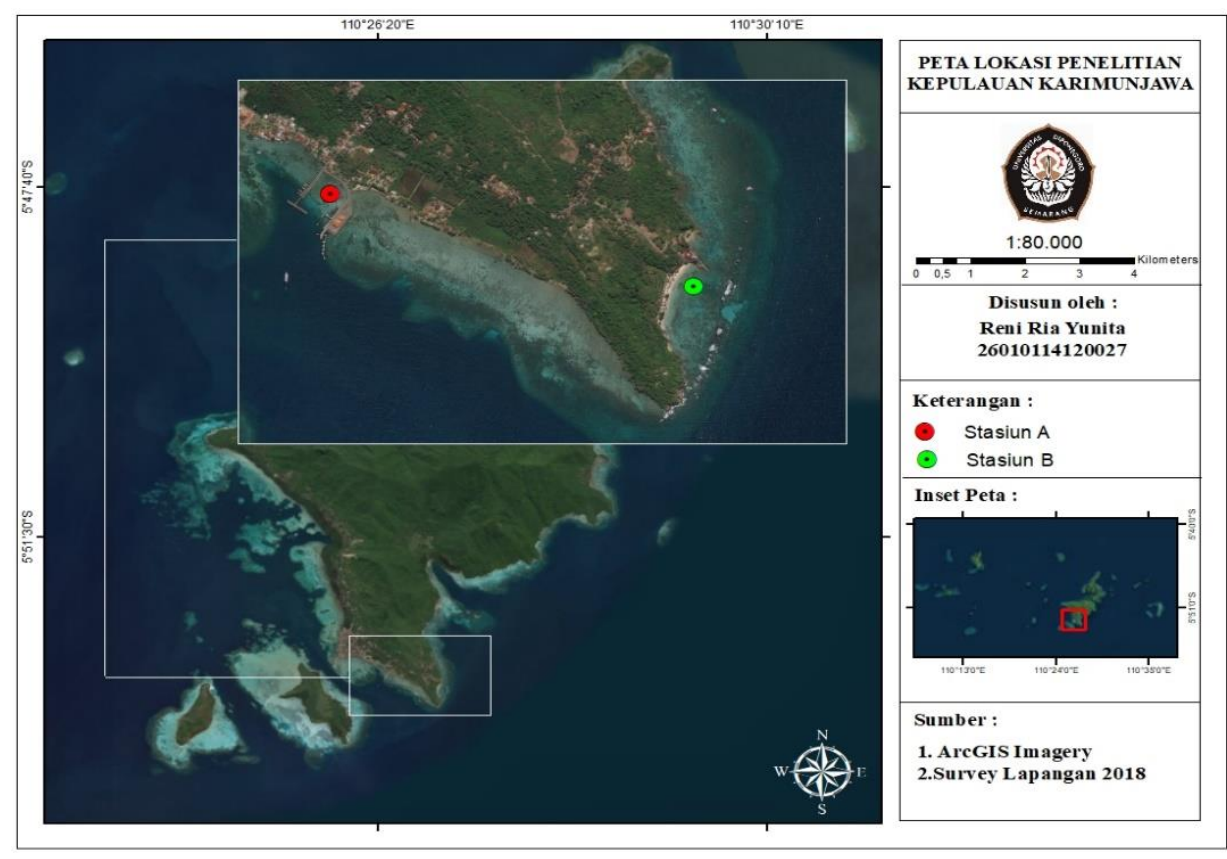

Gambar 1. Lokasi penentuan titik samplig

Sampling dilakukan di dua stasiun berdasarkan tingkat aktivitas manusia, stasiun A merupakan lokasi dengan aktivitas manusia yang tinggi, dekat dengan pemukiman penduduk dan alur pelayaran yaitu di sekitar dermaga, sedangkan stasiun $B$ merupakan lokasi dengan aktivitas manusia yang rendah yaitu di pantai Pancuran dimana lokasi ini digunakan untuk pariwisata namun tidak banyak wisatawan yang datang, karena akses menuju lokasi yang sulit dan terjal. Pemilihan 2 stasiun ini adalah untuk mengetahui perbedaan kerapatan lamun dan kelimpahan Echinodermata pada lokasi dengan tingkat aktivitas manusia yang berbeda. Penentuan sampling dilakukan pada saat pagi hari, dikarenakan Echinodermata bersifat nocturnal (aktif pada 
malam hari), selain itu sampling dilakukan pada saat keadaan surut dengan tujuan untuk memudahkan pengamatan.

\section{HASIL DAN PEMBAHASAN}

Stasiun A terletak di dekat dermaga penyeberangan dengan substrat dasar bepasir dan pecahan karang. Sedangkan pada stasiun B substrat dasar tersusun oleh pasir kasar, pasir halus, pasir berlumpur, dan pecahan karang yang terletak di daerah sekitar pantai Pancuran. Kondisi arus perairan di stasiun $B$ relative lebih tenang dibandingkan dengan stasun $A$, hal ini dikarenakan pada stasiun dekat dengan alur pelayaran sehingga arus lebih besar dari stasiun B. meskipun memiliki kondisi substrat dan arus yang berbeda, namun kedua lokasi penelitian memiliki tingkat kecerahan yang sama. Kecerahan pada lokasi penelitian adalah tak terhingga dimana cahaya matahari mampu menembus hingga ke dasar perairan. Hal ini sangat penting bagi lamun untuk melakukan proses fotosintesis. Nybakken (1992) menyatakan bahwa dalam melakukan proses fotosintesis lamun membutuhkan suhu optimum antara $25^{\circ} \mathrm{C}$ $35^{\circ} \mathrm{C}$ dan saat cahaya penuh. Suhu perairan di Pulau karimunjawa pada kedua stasiun berkisar antara 28-30 ${ }^{\circ} \mathrm{C}$. Hasil yang didapatkan hasil sama dengan penelitian terdahulu Ali et al., (2016) bahwa suhu perairan Pulau Karimunjawa berkisar $29^{\circ} \mathrm{C}$ $30^{\circ} \mathrm{C}$. Hal serupa juga dikatan oleh Ziemen
(1980) bahwa lamun daerah tropis umumnya tumbuh optimal pada suhu $28-30^{\circ} \mathrm{C}$ dengan salinitas $20-35 \%$.

Hasil penelitian menunjukan bahwa perbedaan kondisi perairan di kedua lokasi tersebut juga berpengaruh terhadap lamun yang tumbuh. Pada stasiun A jenis lamun yang ditemukan terdapat 4 jenis meliputi Thalassia hemprichii, Cymodocea rotundata, Enhalus acoroides dan Syringodium isoetifolium sedangkan pada stasiun B ditemukan 7 jenis lamun yaitu Thalassia hemprichii, Cymodocea rotundata, Cymodocea serrulata, Enhalus acoroides, Syringodium isoetifolium, Halophila minor, Halophila ovalis dan Halodule uninervis. Adapun jenis dan kerapatan individu lamun di Pulau Karimunjawa tersaji pada Gambar 2.

Perbedaan jenis lamun yang ditemukan pada kedua stasiun dan perbedaan kerapatan disebabkan karena karakteristik dari masing-masing stasiun. Stasiun A merupakan daerah dekat dermaga dimana dekat dengan aktivitas manusia dan aktivitas pelayaran, sehingga jenis lamun yang ditemukan lebih sedikit dengan kerapatan yang rendah. Hal tersebut didukung dari hasil penelitian Feryatun et al., (2014) menyatakan bahwa daerah yang terganggu aktivitas manusia memiliki penutupan lamun yang rendah dan akan semakin tinggi pada daerah yang alami. Hal ini dikarenakan gangguan ekosistem yang diterima lamun akibat pembuangan limbah rumah tangga

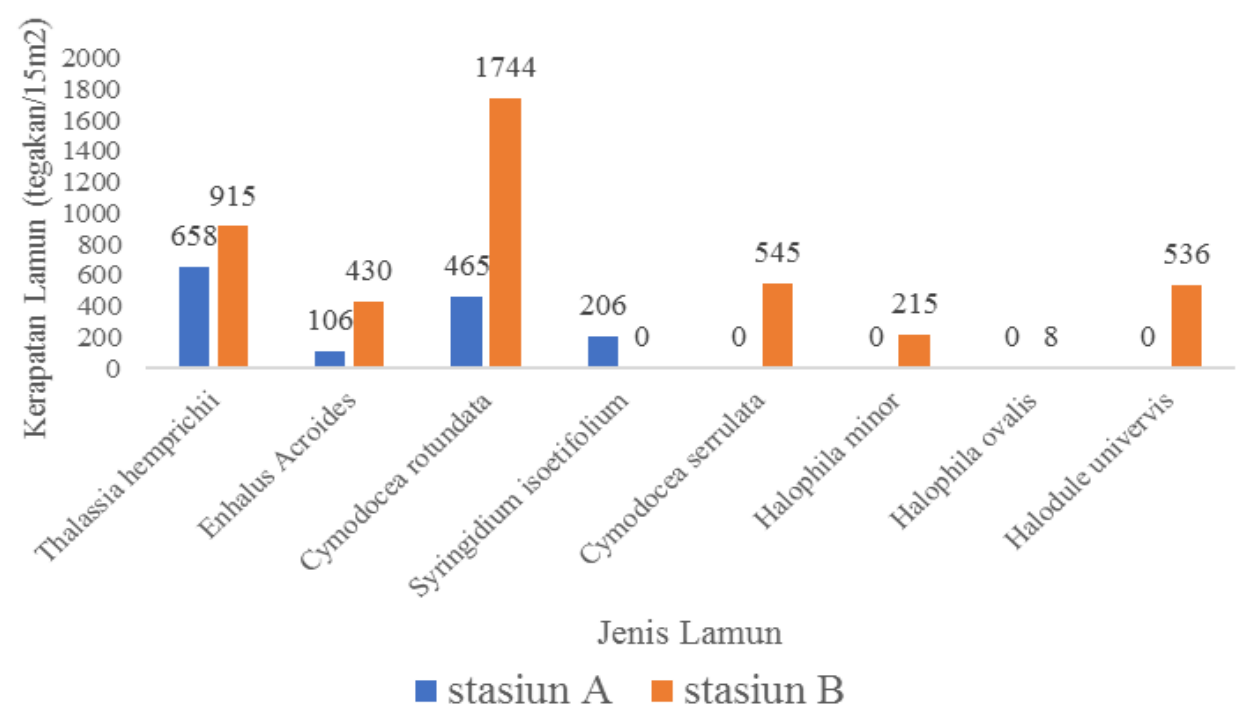

Gambar 2. Kerapatan jenis lamun pada stasiun yang berbeda di perairan Pulau Karimunjawa 
serta aktivitas masyarakat. Stasiun B merupakan daerah di sekitar Pantai Pancuran yang relatif jauh dari aktivitas manusia sehingga terdapat lebih banyak jenis lamun yang dijumpai dengan kerapatan yang tinggi.

Thalassia hemprichii merupakan jenis lamun yang banyak ditemui pada stasiun $A$, sedangkan pada stasiun $B$ disominasi oleh Cymodocea rotundata. Di stasiun A banyak ditemukan jenis lamun Thalassia hemprichii dikarenakan pada stasiun A memiliki substrat yang cocok untuk mendukung kehidupan lamun jenis Thalassia hemprichii. Stasiun A memiliki substrat pasir kasar hingga pecahan karang. Menurut Alie (2010) bahwa Thalassia hemprichii merupakan lamun yang paling melimpah dan dominan tumbuh pada substrat pasir hingga pecahan kasar. Cymodocea rotundata merupakan lamun yang mudah beradaptasi dengan lingkungan. Berdasarkan penelitian Riniatsih dan Endrawati (2013) bahwa tingkat kehidupan transplantasi lamun jenis Cymodocea rotundata sebesar 100\% menunjukan bahwa lamun jenis ini merupakan lamun yang mudah untuk beradaptasi dan dapat tumbuh pada berbagai kondisi lingkungan.

Echinodermata yang ditemukan di lokasi penelitian terdiri dari 3 kelas yang berbeda yaitu Asteroidea, Echinodea, dan Holothuroidea. Kelas Asteroidea terdapat 1 jenis yaitu Archaster typicus, kelas Echinoidea terdiri dari 3 jenis yaitu Diadema setosum, laganum central, dan laganum depressum, sedangkan kelas Holothuroidea dijumpai 1 jenis yaitu Holothuria atra. Kelimpahan Echinodermata tertinggi yaitu jenis Holothuria atra. Menurut Yusron (2009) bahwa Holothuria atra adalah spesies yamg umum ditemukan di perairan Indonesia. Kelimpahan Echinodermata di suatu lokasi dipengaruhi oleh lingkungan baik faktor biotik dan abiotik yang saling terkait satu dengan yang lain serta interaksi antara berbagai spesies yang membentuk sistem tersebut (Hadi, 2011). Salah satu faktor yang berpengaruh terhadap kelimpahan Echinodermata adalah salinitas. Salinitas pada pada lokasi penelitian menunjukan nilai 30 \%. Nilai tersebut sesuai untuk kehidupan
Echinodermata, sesuai dengan pernyataan dari Hyman (1955) bahwa Echinodermata mampu hidup pada kisaran salinitas antara 29-34 \%. Kisaran pH pada lokasi penelitian yaitu 8.

Tipe substrat pada stasiun A yaitu pasir kasar dan pecahan karang sedangkan pada stasiun B yaitu pasir halus dan pasir kasar. Substrat sangat berpengaruh terhadap Echinodermata. Perbedaan substrat pada kedua stasiun juga berpengaruh terhadap kandungan bahan organik pada sedimen. Kandungan bahan pada stasiun B lebih tinggi dari stasiun A yaitu mencapai 8,8\%. Menurut Riniatsih dan Kushartono (2009) ukuran butir sedimen turut mempengaruhi kandungan bahan organik dalam sedimen atau dapat dikatakan semakin kecil ukuran partikel sedimen semakin besar kandungan bahan organiknya. Meskipun kandungan bahan organik pada stasiun B lebih tinggi dari stasiun A, namun hal ini berlawanan dengan kelimpahan Echinodermata, dimana Echinodermata pada stasiun A lebih tinggi dari pada stasiun B. Hal ini disebabkan karena tidak semua Echinodermata mampu bertahan hidup pada kadar bahan organik sedimen yang tinggi, salah satunya adalah bulu babi. Menurut Nybakken (1992) kandungan bahan organik yang tinggi dalam substrat tidak selamanya menguntungkan bagi kehidupan bulu babi walaupun bahan organik merupakan bahan makanannya, karena jika terlalu banyak akan menyumbat alat pernafasan.

Echinodermata bersifat pemakan detritus, sehingga peranannya dalam suatu ekosistem untuk merombak sisa-sisa bahan organik yang tidak terpakai, adanya buangan sampah organik dari aktivitas pemukiman menjadi makanan bagi Echinodermata (Katili, 2011). Jenis dan jumlah Echinodermata (Tabel 1).

Pola sebaran dari jenis Echinodermata diketahui dari nilai varian dan mean dari masing-masing jenis. Jenis Archaster typicus dan Diadema setosum memiliki nilai Varian dan Mean yang sama, hal ini dikarenakan jumlah individu yang ditemukan pada kedua jenis tersebut sama. Pola sebaran dari Archaster typicus dan Diadema setosum adalah mengelompok. Hal ini sesuai dengan 
pernyataan Laning et al., (2014) bahwa Diadema setosum lebih sering ditemukan pada area berpasir dan hidup mengelompok. Pola sebaran Holothuria atra berdasarkan perhitungan menunjukan pola sebaran yang mengelompok. Holothuria atra mengelompok untuk memenuhi kebutuhan pakan dan reproduksi. Menurut Ali et al., (2016) pola sebaran dari kelas Holothroidea mengelompok (clumped). Pola sebaran Echinodermata yang ditemukan tersaji pada tabel 2.

Diadema setosum adalah salah satu jenis dari kelas Echinoidea yang ditemukan di stasiun A dan stasiun B. Diadema setosum mampu hidup pada ekosistem lamun maupun ekosistem terumbu karang. Keberadaan Diadema setosum dalam suatu ekosistem mempunyai peranan yang sangat penting. Menurut Suryanti et al., (2017) salah satu jenis bulu babi (Echinoidea) yang banyak ditemukan di ekosistem terumbu karang dan ekosistem lamun adalah Diadema setosum, sedangkan menurut Rumahlatu (2012) Diadema setosum merupakan spesies yang mempunyai peran indikator dalam komunitas lamun.

Bulu babi dikatakan sebagai spesies kunci karena mampu mengontrol pertumbuhan makroalga. Bulu babi yang bersifat herbivor dapat melakukan grazing pada populasi makroalga agar tidak terjadi eutrofikasi. Menurut Suryanti et al., (2018) bahwa bulu babi merupakan spesies kunci yang mampu mengontrol populasi makroalga, sehingga terjadi hubungan yang saling menguntungkan (simbiosis mutualisme). Kelimpahan individu Diadema setosum pada Stasiun A lebih tinggi dari pada stasiun B meskipun stasiun A merupakan kawasan dekat dermaga yang dekat dengan pemukiman masyarakat dan aktivitas pelayaran. Hal ini mengindikasikan bahwa Diadema setosum memiliki daya adaptasi yang tinggi karena mampu hidup pada kondisi dengan tekanan yang tinggi. Diadema setosum mampu bertahan hidup dengan paparan cadmium (Cd), semakin tinggi paparan cadmium maka Diadema setosum akan mengalami perubahan seperti

Tabel 1. Kelimpahan Echinodermata pada stasiun yang berbeda di Perairan Pulau Karimunjawa

\begin{tabular}{|c|c|c|c|c|c|c|c|}
\hline \multirow{2}{*}{ No. } & \multirow{2}{*}{ Jenis Echinodermata } & \multicolumn{3}{|c|}{ Stasiun A } & \multicolumn{3}{|c|}{ Stasiun B } \\
\hline & & I & II & III & $\mathrm{I}$ & II & III \\
\hline \multicolumn{8}{|c|}{ Kelas Asteroidea } \\
\hline 1. & Archaster typicus & 1 & 2 & - & - & - & - \\
\hline \multicolumn{8}{|c|}{ Kelas Echinoidea } \\
\hline 2. & Diadema setosum & 1 & - & 1 & - & 1 & - \\
\hline 3. & Laganum central & 1 & - & 1 & 1 & 1 & - \\
\hline & Laganum depressum & - & 2 & 2 & 1 & - & 1 \\
\hline \multicolumn{8}{|c|}{ Kelas Holothuroidea } \\
\hline & Holothuria atra & 2 & 3 & 2 & 2 & 1 & 1 \\
\hline & $\sum$ individu (ind $/ 5 \mathrm{~m}^{2}$ ) & 5 & 7 & 6 & 4 & 3 & 2 \\
\hline & $\sum$ seluruh individu (ind $/ 15 m^{2}$ ) & & 18 & & & 9 & \\
\hline
\end{tabular}

Tabel 2. Pola Sebaran Jenis Echinodermata di Perairan Pulau Karimunjawa

\begin{tabular}{cccc}
\hline Spesies & Nilai Varian & Nilai Mean & Pola Sebaran \\
\hline Archaster typicus & 1 & 0,111 & Clumped \\
Diadema setosum & 1 & 0,111 & Clumped \\
Laganum central & 0,816 & 0,148 & Clumped \\
Laganum depressum & 0,632 & 0,222 & Clumped \\
Holothuria atra & 0,447 & 0,407 & Clumped \\
\hline
\end{tabular}


lepasnya duri dan penutupan duri (spine closure). Menurut Urriago et al., (2011) bahwa perilaku menutup dari bulu babi meniru kebiasaan alaminya untuk menghindari diri dari predator dan stressor lingkungan oleh logam berat.

Holothuria atra dapat dijumpai pada berbagai habitat mulai dari lamun, pasir, alga maupun substrat yang keras seperti karang dan batu. Hal tersebut yang menyebabkan Holothuria atra memiliki kelimpahan tertinggi. Holothuria atra merupakan jenis dengan jumlah individu tertinggi yang ditemukan di semua habitat, antara lain, lamun, makroalga, terumbu karang, karang mati, pasir serta bawah batu dan pada kondisi surut Holothuria atra ditemukan dalam keadaan membenamkan diri di pasir dan juga beberapa individu ditemukan dengan butiran pasir halus yang menempel di pada tubuhnya (Budiman et al., 2014). Lambert (2010) menyatakan bahwa Holothuria atra mempunyai mekanisme pertahanan diri yang tinggi, dimana Holothuria atra menempeli tubuhnya dengan butiran-butiran pasir. Pasir yang menempel pada tubuh Holothuria atra memantulkan cahaya dan memnuat suhu tubuhnya lebih rendah (Angreni et al., 2017). Holothuria atra merupakan jenis yang paling banyak ditemukan dibandingkan dengan jenis lain dikarenakan nilai ekonomisnya yang rendah dibanding dengan jenis lain, sehingga di alam masih banyak dijumpai. Hal ini sesuai dengan penilitian Yusron (2009) bahwa Holothuria atra adalah spesies yamg umum ditemukan di perairan Indonesia.

Archaster typicus adalah satu-satunya jenis dari kelas Asteroidea yang ditemukan pada stasiun A yang di dominasi oleh lamun jenis Thalassia hemprichii dengan kerapatan yang rendah dan substrat dominasi pasir. Menurut Clark and Rowe (1971) populasi Archaster typicus ditemukan di daerah pasang surut (intertidal) dengan substrat pasir, karang, tersebar di wilayah indo-pasifik barat. Jenis bintang laut Archaster typicus memiliki sifat berpasangan antara jantan dan betina saat musim pemijahan.

$\begin{array}{clr}\text { Kelas } & \text { Asteroidea } & \text { mampu } \\ \text { menyesuaikan } & \text { diri dengan kondisi }\end{array}$

lingkungan. Pada saat kondisi air laut surut, bintang laut melakukan penyesuaian dengan membenamkan diri di dalam pasir. Spesies Archaster typicus memiliki sisi aboral yang terdiri atas madreporit sebagai system sirkulasi air dan anus, pada bagian oral ditemukan mulut, bukaan ambulakral dan kaki tabung berbentuk silinder. Spesies ini memiliki duri putih, berbentuk tumpul dan pipih (Suwartimah et al., 2017). Spesies ini tersebar di selatan Samudra Hindia, Mascarane, Timur Afrika(Madagaskan) Maldive, Teluk Bengal, Timur India, Utara Australia, Filipina, china, Jepang, Selatan Pasifik dan Hawaii (Clark dan Rowe, 1971)

Struktur komunitas Echinodermata terdiri dari indeks keanekaragaman, indeks keseragaman dan indeks dominansi . Indeks keanekaragaman ( $\left.\mathrm{H}^{\prime}\right)$ Echinodermata pada stasiun A sebesar 1,49 dan stasiun B sebesar 1,27. Hal tersebut menandakan bahwa keanekaragaman Echinodermata di Pulau Karimunjawa adalah keanekaragaman sedang. Menurut Rahma dan Fitriana (2006) nilai indeks keanekaragaman $1,0 \leq \mathrm{H} \leq 3,322$ adalah kaeanekaragaman sedang, produktivitas cukup, kondisi ekosistem cukup seimbang, tekanan ekologis sedang.

Indeks keseragaman Echinodermata pada stasiun A sebesar 0,92 dan pada stasiun $B$ sebesar 0,91. Nilai indeks keseragaman antara dua stasiun tersebut hampir sama dikarenakan spesies yang ditemukan hampir sama di kedua lokasi tersebut. Nilai indeks keseragaman yang di dapatkan pada kedua stasiun tinggi dan menandakan bahwa kondisi komunitas dalam suatu ekosistem tersebut stabil. Menurut Supono dan Arbi, (2010) Suatu komunitas bisa dikatakan stabil bila mempunyai nilai indeks keseragaman jenis mendekati angka 1, dan sebaliknya dikatakan tidak stabil jika mempunyai nilai indeks keseragaman jenis yang mendekati angka 0.

Nilai indeks dominansi pada stasiun $A$ sebesar 0,25 dan pada stasiun B sebesar 0,31. Nilai tersebut termasuk dominasi rendah, pada dua stasiun memiliki indeks dominasi rendah yang menandakan bahwa tidak ada spesies yang dominasi pada kedua stasiun 


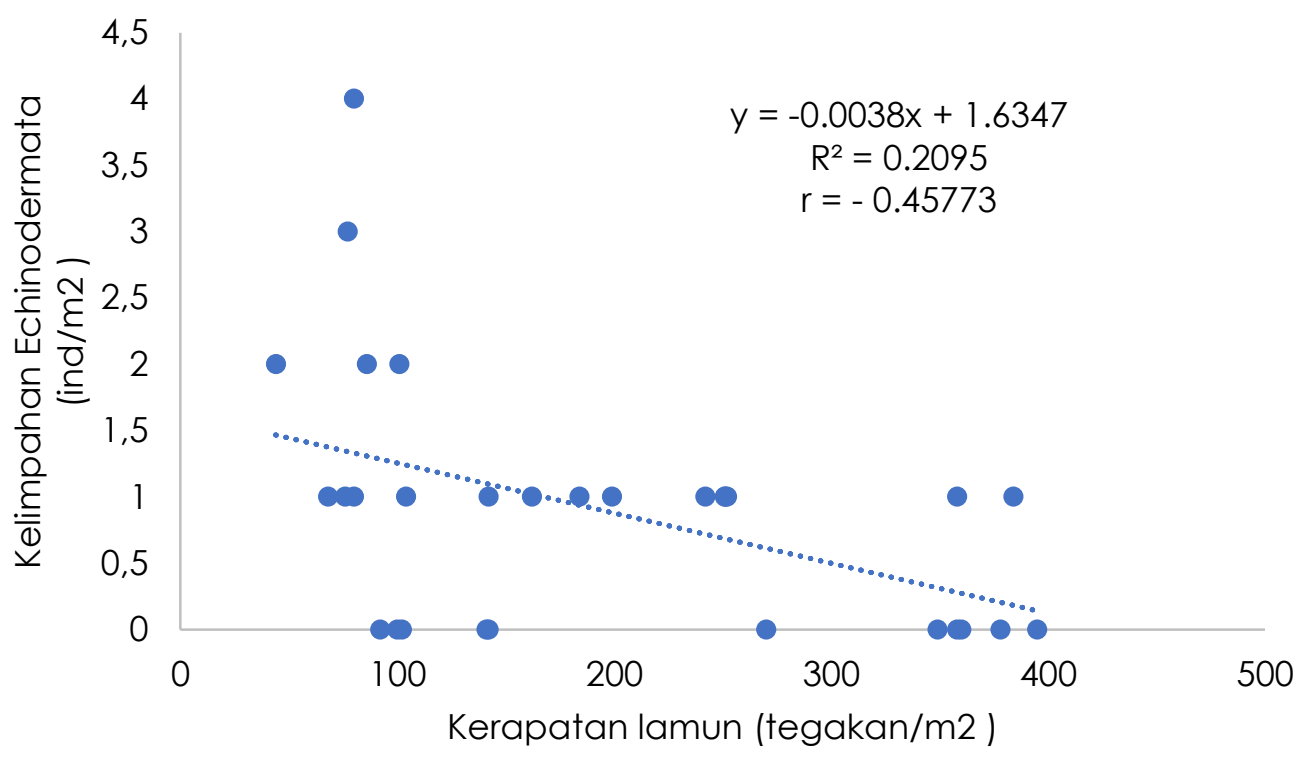

Gambar 3. Hubungan Kerapatan Lamun dengan Kelimpahan Echinodermata

tersebut. Menurut Leksono (2007), dominansi terjadi karena adanya hasil dari proses kompetisi penggusuran individu satu terhadap yang lain.

Hubungan antara kerapatan lamun dengan kelimpahan Echinodermata di Pulau Karimunjawa diolah menggunakan software Ms. Excel. Dari hasil pengolahan tersebut didapatlah hasil yang tersaji pada Gambar 3. Nilai koefisien korelasi antara variabel kelimpahan Echinodermata dan kerapatan lamun diperoleh nilai (r) sebesar -0,458. Koefisien korelasi bernilai negatif dikarenakan nilai-nilai koefisien regresi (b) bernilai negatif juga. Hubungan antara dua variabel juga ditandai dengan garis lurus yang bernilai negatif. Nilai korelasi yang didapat menunjukan bahwa hubungan antara kerapatan lamun dan kelimpahan Echinodermata cukup erat dan arah hubungannya berbanding terbalik semankin rapat lamun maka kelimpahan Echinodermata semakin rendah. Hal ini dikarenakan tidak semua Echinodermata menyukai kondisi lamun yang lebat, seperti Archaster typicus yang menyukai daerah berpasir. Hasil korelasi yang didapatkan sesuai dengan hasil penelitian dari Oktavianty et al., (2014) bahwa hubungan antara kerapatan lamun dan kelimpahan Echinodermata arah hubunganya berlawanan ditandai dengan garislurus yang bernilai negatif karena semakin padat kerapatan lamun maka semakin sedikit kelimpahan Echinodermatabahkan hampir tidak ada. Nilai koefisien determinasi $\left(R^{2}\right)$ sebesar 0,209 menunjukan seberapa besar pengaruh kerapatan lamun terhadap kelimpahan Echinodermata. Nilai 0,209 menunjukan bahwa sebesar 20,90 \% kelimpahan Echinodermata dipengaruhi oleh kerapatan lamun dan sisanya 79,10 \% dipengaruhi oleh faktor lain seperti faktor lingkungan maupun Echinodermata itu sendiri. Hal ini berkaitan dengan fisiologi Echinodermata serta pola pertumbuhan Echinodermata itu sendiri. Menurut Hadi (2011) Keberadaan dan kelimpahan Echinodermata di suatu lokasi dipengaruhi oleh lingkungan baik faktor biotik dan abiotik yang saling terkait satu dengan yang lain serta interaksi antara berbagai spesies yang membentuk sistem tersebut.

\section{KESIMPULAN}

Berdasarkan hasil penelitian dapat disimpulkan bahwa terdapat 8 jenis lamun yang di dominasi oleh Thalassia hemprichi dan Cymodocea rotundata. Echinodermata yang ditemukan terdiri dari 5 jenis yaitu Archaster typicus, Diadema setosum, Laganum central, Laganum depressum dan Holothuria atra. Hubungan antara kelimpahan Echinodermata dan kerapatan 
lamun cukup erat dan arah hubungannya berlawanan yaitu semakin rapat lamun maka Echinodermata yang ditemukan semakin sedikit. Kerapatan lamun hanya berpengaruh sebesar 20,90 \% terhadap kelimpahan Echinodermata.

\section{DAFTAR PUSTAKA}

Ali, A.I., Suryanti \& B. Sulardiono. 2016. Kelimpahan dan Pola Sebaran Echinodermatadi Pulau Karimunjawa Jepara. Dalam : Prosiding Seminar Tahunan Hasil Penelitian Perikanan dan Kelautan VI Tanggal 12 November 2016. Fakultas Perikanan dan IImu Kelautan, Universitas Diponegoro.

Alie, K. 2010. Pertumbuhan dan Biomassa Lamun Thalassia hemprichii di Perairan Pulau Bone Batang Kepulauan Spermonde Sulawesi Selatan. Jurnal Sains MIPA Universitas Lampung. 16(1) : 105110.

Balai Taman Nasional Karimunjawa. 2008. Statistik Balai Taman Nasional Karimunjawa Tahun 2007. Balai Taman Nasional Karimunjawa, Semarang, 133 hlm.

Clark, A.M. \& Rowe, F.E.W.. 1971. Monograph of Shallow-water Indo West Pasific Echinoderms. Trustees od the British Museum. London. p. 238.

Azkab, H.M. 2006. Ada Apa dengan Lamun. Jurnal Oseana, 31 (3): 45-55.

Effendi, H. 2003. Telaah Kualitas Air bagi Pengelolaan Sumberdaya dan Lingkungan. Kanisius. Yogyakarta, 258 $\mathrm{hlm}$.

Fachrul, F.M. 2006. Metode Sampling Bioekologi. PT. Bumi Aksara, Jakarta, 198 hlm.

Feryatun, F., B. Hendrarto, \& N. Widyorini. 2012. Kerapatan Dan Distribusi Lamun (Seagrass) Berdasarkan Zona Kegiatan Yang Berbeda Di Perairan Pulau Pramuka, Kepulauan Seribu. Journal of Management of Aquatic Resources, $1(1): 44-50$

Hadi, A., Hartati, R. \& Widianingsih. 2011. Fauna Echinodermata di Indonoor Wreck, Pulau Kemujan, Kepulauan Karimunjawa. Ilmu Kelautan: Indonesian Journal of Marine Sciences, 16(4):236-242.
Hartati, R., Djunaedi, A., Haryadi, \& Mujiyanto. 2012. Struktur Komunitas Padang Lamun di Perairan Pulau Kumbang, Kepulauan Karimunjawa. Ilmu Kelautan: Indonesian Journal of Marine Sciences, 17(4):217-225.

Heiri, O., Lotter, A.F. \& Lemcke, G. 2001. Loss on ignition as a method for estimating organic and carbonate content in sediments: reproducibility and comparability of results. Journal of Paleolimnology. 25:101-110.

Hyman, L. H. 1995. The Invertebrates Echinodermata The Coelomate Bilateris. Vol. 3 IV. Mc Graw-Hill Book Company. Inc. New York- Toronto-London. 763.

Iken, K., Konar, B., Benedetti-Cecchi, L., CruzMotta, J.J. \& Knowlton, A. 2010. LargeScale Spatial Distribution Patterns of Echinoderms in Nearshore Rocky Habitats. PLOSONE 5(11): p.e13845.

Katili, A.S. 2011. Struktur Komunitas Echinodermata pada Zona Intertidal di Gorontalo di Gorontalo. Jurnal Penelitian dan Pendidikan, 8(1):51-61.

Kawaroe, M., Nugraha, A.H., Juraij \& Tasabaramo, I.A. 2016. Seagrass Biodiversity at Three Marine Ecoregions of Indonesia: Sunda Self, Sulawesi Sea, and Banda Sea. Jurnal Biodiversitas, 17 (2):585591.

Lambert, P. 2010. Sea Cucumbers of British Colombia, Southest Alaska and Puget Sound. British Colombia. UBC Press.

Laning, T.H., Yusup, D.S. \& Wiryanto, J. 2014. Sebaran Bulu Babi (Echinoidea) Di Kawasan Padang Lamun Pantai Merta Segara, Sanur-Bali. Jurnal Biologi 18(2):4145.

Leksono, A.S. 2007. Ekologi: Pendekatan Deskriptif dan Kuantitatif. Bayumedia Publishing . Malang.

McKenzie L.J., and R.L. Yoshida. 2009. Seagrass-Watch: Proceeding of workshop for monitoring seagrass habitats in Indonesia. The Nature Conservancy, Coral Triangle Center, Sanur, Bali. 9th May 2009. SeagrassWatch $\mathrm{HQ}$, Cairns.

Nybakken. J.W. 1992. Biologi Laut. Suatu Pendekatan Ekologis. PT Gramedia. Jakarta, $459 \mathrm{hlm}$.

Odum, E.P. 1971. Fundamental Of Ecology. 3rd Edition. W.B Saunders Company, Philadelphia. 
Oktavianti, R., Suryanti \& Purwanti, F. 2014. Kelimpahan Echinodermata Pada Ekosistem Padang Lamun Di Pulau Panggang, Kepulauan Seribu, Jakarta. Diponegoro Journal of Maquares, 3(4): 243-249.

Rahma, Y. \& Fitriana. 2006. Keanekaragaman dan Kemelimpahan Makrozoobenthos di Hutan Mangrove Hasil Rehabilitasi Taman Hutan Raya Ngurah Rai, Bali.

Riniatsih, I. \& Kushartono, E.W.. 2009. Substrat Dasar dan Parameter Oseanografi sebagai Penentu Keberadaan Gastropoda dan Bivalvia di Pantai Sluke Kabupaten Rembang. Jurnal IImu Kelautan, 14(1):50-59.

Riniatsih, I., \& Endrawati, H. 2013. Pertumbuhan Lamun Hasil Transplantasi Jenis Cymodocea rotundata di Padang Lamun Teluk Awur Jepara. Buletin Oseanografi Marina, 2(1):34-40.

Rumahlatu, D. 2011 . Respon Perilaku Bulu Babi Deadema setosum terhadap Logam Berat Kadmium. Jurnal Bumi Lestari, 12(1):45-54.

Rumahlatu, D., 2012. Konsentrasi logam berat kadmium pada air, sedimen dan Deadema setosum (Echinodermata, Echinoidea) di Perairan Pulau Ambon. IImu Kelautan: Indonesian Journal of Marine Sciences, 16(2):78-85.

Budiman, C.C., Maabuat, P.V., Langoy, M.L. and Katili, D.Y., 2014. Keanekaragaman Echinodermata di Pantai Basaan Satu Kecamatan Ratatotok Sulawesi Utara. Jurnal MIPA, 3(2):97-101.

Supono and U.Y. Arbi. 2010. Struktur Komunitas Ekhinodermata Di Padang Lamun Perairan Kema, Sulawesi Utara. Oseanologi dan Limnologi di Indonesia, 36(3):329-342.

Supono, D. J. W. Lane and Susetiono. 2014. Echinoderm Fauna in Lembeh Strait, North Sulawesi: Inventory and Distribution Review. Marine Research Indonesia, 39 (2):51-61.

Suryanti, Ain, C. \& Latifah, N. 2018. Mapping of Nitrate, Phospat and Zooxanthelae with Abundance of Sea Urchin on Massive Coral Reef in Karimunjawa Island. IOP Conference Series: Earth and Environmental science, 116(1):1-8.
Suryanti, Ain, C., Latifah, N. \& Febrianto, S. 2017. Mapping of Sea Urchin Abundance as Control of Expansion for the Balance of Coral Reef Ecosystem in Karimunjawa Island. Journal of Applied Environmental and Biological Sciences, 7(12):120-127.

Suryanti, M.R. Muskananfola dan K.E. Simanjuntak. 2016. Sand Dollar Distribution Pattern and Abundance at the coast of Cemara Kecil Island, Karimunjawa, Jepara, Indonesia. Jurnal Teknologi, 78 (4-2) : 239-244.

Suwartimah, K., D. S. Wati, H. Endrawati, dan R. Hartati. $2017 . \quad$ Komposisi Echinodermata di Rataan Litoral Terumbu Karang Pantai Krakal, Gunung Kidul, Yogyakarta. Buletin Oseanografi Marina, 6 (1):53-60.

Urriago, J.D., J.H. Himmelman, and C.F. Gaymer. 2011. Responses of the Black Sea Urchin Tetrapygus niger to its Sea-star Predators Heliaster heliantus and Meyenaster gelatinous under Field Conditions. Journal of Experimental Marine Biology and Ecology, 399: 17-24.

Yusron, E. 2009. Biodiversitas fauna ekhinodermata di perairan Selat Lembeh, Bitung-Sulawesi Utara. Oseanologi dan Limnologi di Indonesia, 35(2): 225-237.

Yusron, E. 2010. Keanekaragaman Echinodermata di Perairan Likupang, Minahasa Utara, Sulawesi Utara. IImu Kelautan: Indonesian Journal of Marine Sciences, 15(2):85-90.

Yusron, E. 2013. Biodiversitas Fauna Ekhinodermata (Holothuroidea, Echinoidea, Asteroidea Dan Ophiuroidea) Di Perairan Pulau Lombok, Nusa Tenggara Barat. Zoo Indonesia, 22 (1):1-10.

Yusron, E. 2016. Struktur Komunitas Ekhinodermata(Asteroidea, Ophiuroidea, Echinoidea Dan Holothuroidea) Di Perairan Taman Nasional Wakatobi Sulawesi Tenggara. Jurnal IImu dan Teknologi Kelautan Tropis, 8(1):357-366.

Ziemen, J.C. 1980. Produktivity in Ecology of the Indonesia Seas. Part One. Periplus Edition (HK) Ltd., Singapore. 